Croatian Journal of Education

Vol.18; No.3/2016, pages: 755-777

Original research paper

\title{
Turkish Students' Demotivation to Study English: A Scale Development
}

Kerim Unal and Tugba Yanpar Yelken

Faculty of Education, Mersin University

\section{Abstract}

The purpose of this study is to develop a scale that reveals factors adversely affecting the university preparatory class students' motivation for the English language and English language classes. The sample included 454 student participants. The researchers used a 6-point Likert-type scale with 50 items to collect the research data. The results of the exploratory factor analysis indicated that the scale has one factor having four-subcomponent factorial structure with 20 items. The subcomponents of the scale are 1) teacher characteristics, 2) lack of interest towards English and English classes, 3) class environment and class materials, and 4) experience of failure. Cronbach Alpha coefficient for the reliability of the scale was 0.911. Cronbach Alpha coefficients for the subcomponents were 0.847;0.813;0.780 and 0.768 respectively. The results of CFA indicated that factor structure fits the data. The scale is a reliable and a valid tool for measuring the factors demotivating the students in their language learning process.

Key words: demotivation; demotivating factors; demotivation scale; ELT; language preparatory classes.

\section{Introduction}

Motivation is one of the crucial factors affecting the language learning process, and has a direct impact on students' efforts, application of the necessary learning strategies, willingness to use the target language, and success on exams administered at school (Scarcella \& Oxford, 1992; Spolsky, 1989). For this reason, it is vital that students be highly motivated to be successful in learning the target language. However, students' motivation is subject to many negative influences during the process of target language learning (Dörnyei \& Ushioda, 2011; Falout, Elwood, \& Hood, 2009; 
Falout \& Maruyama, 2004; Kikuchi, 2009; Kikuchi \& Sakai, 2009). These influences diminish their motivation at the beginning of their target language learning process in time. Dörnyei refers to this as demotivation, i.e. "specific external forces that reduce, or diminish the motivational basis of a behavioral intention or an ongoing action" (Dörnyei \& Ushioda, 2011, p. 139). Moreover, Dörnyei and Ushioda (2011, p. 138) identified three situations where negative factors affect students' motivation. The first of these are learning-related situations, or experiences, such as success anxiety, social pressure, heavy workload, or low exam scores. The second one is related to factors in the social learning environment. These factors can be peer pressure, personality, and attitudes of peers, or teachers. The third situation is about the social context beyond the classroom environment where discourse and attitudes of the community can hinder the language-learning process.

Yet, as Dörnyei and Ushioda stated (2011), not all events occurring in these situations affect the students' motivation. If students have strong distractors bearing no negative value, lose their interest gradually, or suddenly realize the cost of the action they are pursuing, such situations cannot be considered as demotivating factors.

Demotivation has negative effects on the language learning process and outcomes. It can adversely affect the attitudes and behaviors of students towards English, English classes, or the language teacher, and thus hinder teacher motivation and group dynamics. It also brings about widespread and long-term negative learning outcomes (Falout et al., 2009). Once demotivated, students start to have difficulties in learning the target language and the learning process becomes less pleasant for them. The achievement of expected learning outcomes eventually becomes difficult (Falout et al., 2009).

Therefore, in order to create a successful language-learning environment, teachers should continuously be attentive to their students' motivation and try to reveal the demotivating factors and eliminate them.

There are a few studies, in the literature, focusing on identifying the factors which demotivate students in their language learning process. Dörnyei (1998; in Dörnyei \& Ushioda, 2011) conducted a 10 to 30 -minute structured interview with 50 demotivated students learning either English, or German in Budapest, Hungary. He identified nine demotivating factors: 1) teacher, 2) inadequate school facilities, 3) reduced selfconfidence, 4) negative attitude towards the L2, 5) compulsory nature of L2 study, 6) interference of another foreign language being studied, 7) negative attitude towards L2 community, 8) attitudes of group members, and 9) course book. He found that teacher and reduced self-confidence factors are more demotivating than the other factors mentioned above.

After the interview with 20 Irish college students learning French, Ushioda (1998) found that negative aspects of school environment such as using certain teaching methods are demotivating factors for the students.

Chang and Cho (2003) content-analyzed the essays collected from 91 Taiwanese junior high school students. After the analysis, they reported eight demotivating 
factors: 1) learning difficulties, 2) threats to self-worth, 3) monotonous teaching, 4) poor teacher-student relationship, 5) punishments, 6) general and language-specific anxiety, 7) lack of self-determination, and 8) poor classroom management.

In another study in which students wrote essays on the factors demotivating them, Muhonen (2004) worked with 91 ninth-grade students and identified five demotivating factors: 1) the teacher, 2) learning material, 3) learner characteristics, 4) school environment, and 5) student's attitude towards English.

Trang and Baldauf (2007) asked 100 university students to write an essay about the factors demotivating them. They found 14 demotivating categories, but classified these categories into two groups: 1) internal attributions (such as attitudes towards English, experience of failure, self-esteem), and 2) external attributions (teacher, learning environment, inappropriate workload, etc.).

Falout and Maruyama (2004) investigated the relationship between the students' language proficiency and demotivation. In this study, they developed a 49-item questionnaire based on nine demotivating factors. Dörnyei and Ushioda (2011) identified and administered the questionnaire to 164 junior university students in two science departments. According to the results obtained, they identified six demotivating factors: 1) teacher, 2) classes, 3) attitudes towards English-speaking community, 4) attitudes towards the English language itself, 5) self-confidence, and 6) attitudes of group members. They highlighted that low-proficiency students found self-confidence, attitudes toward the L2 courses, teachers, and attitudes of group members to be the most demotivating factors, while high-proficiency students found self-confidence to be the most important demotivating factor.

In order to identify the factors demotivating Japanese high school learners, Kikuchi (2009) asked five university students from public and private universities to share their experiences in high school English classrooms. Forty-two university students from public universities were asked to complete an open-ended questionnaire prepared after the interview. After the content analysis, the following demotivating factors were identified: 1) teacher behavior, 2) grammar-translation method, 3) tests and entrance examinations, 4) vocabulary memorization, and 5) textbooks and reference books. Traditional teaching methodology and teachers' behavior were found to be the salient demotivating factors in the Japanese context.

Upon reviewing previous studies on student demotivation, Sakai and Kikuchi (2009) identified teachers, characteristics of classes, experiences of failure, class environment, class materials, and lack of interest to be the major demotivating factors. They prepared a 35-item questionnaire and administered it to 656 Japanese high school students, and identified learning contents and materials, teachers' competence and teaching styles, inadequate school facilities, lack of intrinsic motivation, and test scores as the sources of demotivation.

In another study conducted with Japanese students, Falout et al. (2009) administered a 52-item questionnaire they prepared to 900 Japanese university students studying ELT, and according to the data they obtained, they identified nine demotivating factors 
(teacher, help-seeking, enjoyment-seeking, grammar-translation, avoidance, selfdenigration, value and course level), which are different from those mentioned above.

Besides the studies on demotivation in the Japanese context, there exist four studies in the Iranian context. First, Kaivanpanah and Ghasemi (2011) conducted a research study with 327 junior high school, high school and university students, and identified five demotivating factors (teacher, attitude towards second language learning, attitudes towards the English speaking community, learning contents, materials, and facilities and experience of failure) from the data obtained via a 32-item questionnaire.

Second, Meshkat and Hassani (2012) utilized a 21-item questionnaire to obtain data from 421 Iranian high school students and discovered the following factors of demotivation: inadequate school facilities, learning contents and materials, teacher competence and teaching styles, lack of intrinsic motivation and test scores.

Third, Alavania and Sehat (2012) gave a 50-item questionnaire to 165 Iranian high school students in order to identify the demotivating factors. They underlined nine factors demotivating the students in their ESL learning process: 1) learning environment, 2) simultaneous learning of other languages, 3 ) learning material and course content, 4) teaching method, 5) experience of failure, 6) lack of success, 7) teacher's personality and behavior, 8) learners' characteristics, and 9) attitude.

Fourth, Ghadirzadeh, Hashtroudi, and Shokri (2012) administered a 35-item questionnaire prepared by Sakai and Kikuchi (2009) to 260 Iranian university students and found five demotivating factors: 1 ) lack of perceived individual competence, 2) lack of intrinsic motivation, 3) inappropriate characteristics of teachers' teaching methods and course contents, 4) inadequate university facilities and 5) focus on difficult grammar.

When it comes to studies conducted on demotivating factors in the Turkish context, there is one study done with 74 university students by Bekleyen (2011). In this study, Bekleyen (2011), identified 8 demotivating factors from the data obtained by an 11item questionnaire prepared by the researcher and according to Dörnyei's ninefactor classification. The demotivating factors were: 1) teachers, 2) school facilities, 3) students' experience of failure, or success, 4) attitude towards the English language, 5) compulsory nature of English, 6) negative attitude toward English speakers, 7) attitudes of peers, and 8) course books.

In reviewing studies from the literature, it was observed that their order of importance and the demotivating factors themselves vary according to country, grade level, and school types. As compared to other countries, there are not many studies conducted on demotivation in Turkey. For this reason, the aim was to develop a demotivation scale for the EFL classrooms that may help to highlight the factors which demotivate students in their language learning process.

The scale developed is expected to make a significant contribution to the field. Besides, the data obtained from the scale can help school administration, and English language teachers discover the reasons that affect the students' success and level of 
interest, and thus, highlight the effects that increase the level of students demotivation and make necessary plans to eliminate these factors.

\section{Method}

Since the purpose of this study is to develop a scale that highlights the factors which adversely affect the motivation of the university-preparatory classes for English, and the English language, this study can be said to contain fundamental research quality.

\section{Participants}

The data of the study was obtained from 454 students taking English classes at the School of Foreign Languages, Mersin University. Of the total sample, $60.1 \%$ of the participants $(n=273)$ were at the elementary level; 36.3\% $(n=165)$ at pre-intermediate level; and 3.5\% $(n=16)$ at upper-intermediate level. Gender analysis indicated that $50.4 \%$ of the participants $(n=229)$ were female and $49.6 \%(n=225)$ male. The data revealed that $80 \%$ of the students $(n=363)$ were 20 years old or below; $17 \%(n=77)$ were between 21 and $26 ; 3.1 \%(n=14)$ were 27 years old or more.

\section{Instrument}

In the first phase of the scale development, 30 freshmen were asked to write an essay about positive and negative factors they faced in their language learning process, and the effects of these factors on them. By using the data from these essays and related literature, a form with 65 items, which are thought to be indicators of the factors affecting the students' demotivation level towards the English language and English language class, was prepared.

In the second phase, nine experts - Assessment and Evaluation (2), Curriculum and Instructional Design (3), English Language Teaching (2), Psychological Counseling and Guidance (2) - were asked to go through and rank every item in the form from 1 to 10 to show how much it is related to the context.

In the last phase, the marks given for each item were counted, and a mean score calculated. In total, 15 items, the mean score of which was below 6.0 were omitted from the form. A 50-item trial form was prepared by using a 6-point Likert type scale, which was ranked from " 5 - affects me a lot" to "0 - never affects me." In total, 467 students at the School of Foreign Languages in Mersin University filled in the trial form. Thirteen forms were not included in the analysis because they were incomplete.

\section{Data Analysis}

The correlation matrix of the data collected from 454 students at the School of Foreign Languages was scanned. When scanning the correlation matrix, it was assumed that the correlation score was higher than 0.3 and the significant level was 0.000 (Field, 2009). Therefore, the items having a lower correlation score than 0.3 and higher significant level than 0.000 were omitted. After the omission, Exploratory 
Factor Analysis (EFA) was applied for construct validity. In order to identify the items to be in the scale, the following criteria were taken into consideration: 1) Eigen value is at least 1.00 (Shevin \& Lewis, 1999); 2) factor load is at least .30 (Martin \& Newel, 2004; Schriesheim \& Eisenbach, 1995); 3) all the items are in one factor; and 4) there should be at least .10 difference between the factor loads of the items in two factors (Büyüköztürk, 2007).

To see whether the data was suitable for the factor analysis, the results of Bartlett test and Kaiser-Meyer-Olkin (KMO) test were taken into consideration (Kalayc1, 2005; Tavşancil, 2006). Since the item-scale correlation and alpha coefficient ( $\alpha=0.924)$ were high, and it was thought that there was a relationship between the factors, the decision was made to use the Promax rotation, one of the methods used for rotation to distinguish the distribution of the factor loads clearly (Tatlidil, 1992; Erkuş, 2003).

The items with factor loads lower than 0.30 and those existing in more than one factor were left out one by one and the factor analysis was repeated after omitting each item (Çokluk, Şekercioğlu, \& Büyüköztürk, 2010). The analysis was conducted on the factors whose Eigen value was higher than 1.00 Çokluket al., 2010; Köklü, 2002; Tabachnick \& Fidell, 2001).

In order to have supporting evidence about construct validity of the one factor-four subcomponent structure found after the factor analysis using the Promax rotation method and how much this structure agrees with the data, Confirmatory Factor Analysis (CFA) was conducted on the same data set. Chi-squared statistics $\left(\mathrm{X}^{2}\right)$, Root Mean Square Error of Approximation (RMSEA), Comparative Fit Index (CFI), Goodness of Fit Index (GFI), Adjusted Goodness of Fit Index (AGFI), and Standardized Root Mean Square Residual (SRMR) were used to evaluate the validity of the structure.

The reliability of the final scale and subcomponents of the scale were determined by Cronbach Alfa reliability coefficient. In order to get supportive evidence for construct validity of the scale, whether the score of the scale shows difference according to gender, age, faculty, and language level variables was analyzed. Thus, whether the dependent variable showed normal distribution at the levels of dependent variable was checked via normality tests. While the t-test was employed to analyze the difference according to gender, one-way ANOVA analysis was used to see if there were any differences according to age, faculty, and language level. SPSS 20 and LISREL 8.50 software were used for the factor, validity, and reliability analysis.

\section{Results}

\section{Item Analysis}

In the item analysis based on correlation, the items whose correlation coefficient was not zero were identified and those items were excluded from the scale.

\section{Analysis of the Scale's Factor Structure}

As a result of the Bartlett's test of sphericity analysis done for the suitability of the 20item scale for the factor analysis, Chi-Square statistics were significant $\left(\mathrm{X}^{2}=3621.168\right.$, 
$\mathrm{p}<0.05)$ and the KMO score was excellent $(0.924>0.50)$. These two findings showed that the data set was suitable to conduct factor analysis. Principal component analysis results, before the rotation, showed that there were four factors, Eigen values of which were higher than 1.00 . Total variance these four factors explained was $57.857 \%$ and the total variance of each factor explained were $37.461 \% ; 8.452 \% ; 6.772 \%$; and $5.172 \%$ respectively; besides, Eigen values for each factor were $7.492 ; 1.690 ; 1.354$; and 1.034 respectively. Cronbach Alpha coefficient for the reliability of the scale was 0.920 .

Because of the fact that almost all the items are in the first factor and the item-scale correlation and Cronbach Alfa coefficient are high, it was concluded that there is a relationship among the factors. For this reason, factor analysis was repeated using the Promax rotation method, and thus a structure consisting of four factors with 20 items came up. The total variance these four factors explained was $57.857 \%$ and the total variance of each factor explained were $37.461 \% ; 8.452 \% ; 6.772 \%$ and $5.172 \%$ respectively. It was noticed that the Eigen value for the first factor (7.492) is almost five times as high as the Eigen value for the second factor (1.690). Hence, the scale can be concluded to have a common factor as a whole considering both the highness of the total variance explained in the first factor and the difference in the Eigen values between the first and the second factors. Therefore, the scale has a structure of one factor with four subcomponents. Table 1 shows the results of the Promax rotation.

Table 1

Factor analysis results of the 20-item trial form of the scale after Promax rotation

\begin{tabular}{|c|c|c|c|c|c|c|}
\hline \multirow[b]{2}{*}{ Subcomponents } & \multirow[b]{2}{*}{ Items } & \multirow{2}{*}{$\begin{array}{l}\text { Item-Scale } \\
\text { Correlation }\end{array}$} & \multicolumn{4}{|c|}{ Factor Loads } \\
\hline & & & 1 & 2 & 3 & 4 \\
\hline Teacher Characteristics & $\begin{array}{l}47 \\
40 \\
44 \\
36 \\
37 \\
29\end{array}$ & $\begin{array}{l}0.681 \\
0.660 \\
0.684 \\
0.675 \\
0.603 \\
0.678\end{array}$ & $\begin{array}{l}0.803 \\
0.801 \\
0.742 \\
0.697 \\
0.584 \\
0.452\end{array}$ & & & \\
\hline $\begin{array}{l}\text { Lack of Interest towards the English } \\
\text { Language and English Classes }\end{array}$ & $\begin{array}{l}27 \\
34 \\
28 \\
42 \\
35 \\
50\end{array}$ & $\begin{array}{l}0.631 \\
0.639 \\
0.601 \\
0.533 \\
0.680 \\
0.501\end{array}$ & & $\begin{array}{l}0.830 \\
0.755 \\
0.723 \\
0.672 \\
0.523 \\
0.471\end{array}$ & & \\
\hline Class Environment and Class Materials & $\begin{array}{l}19 \\
18 \\
23 \\
16 \\
08\end{array}$ & $\begin{array}{l}0.557 \\
0.575 \\
0.636 \\
0.585 \\
0.526\end{array}$ & & & $\begin{array}{l}0.858 \\
0.701 \\
0.642 \\
0.609 \\
0.587\end{array}$ & \\
\hline Experience of Failure & $\begin{array}{l}24 \\
17 \\
10\end{array}$ & $\begin{array}{l}0.597 \\
0.563 \\
0.586\end{array}$ & & & & $\begin{array}{l}0.794 \\
0.793 \\
0.792\end{array}$ \\
\hline
\end{tabular}

As can be seen in Table 1, there are six items in the first and second subcomponents, five items in the third, and three items in the fourth subcomponent. When the items in the first subcomponent are reviewed, it is seen that it harbors demotivating factors 
related to teacher's personality, language and teaching proficiency, and attitudes towards students. Therefore, it was decided to name this subcomponent Teacher Characteristics. The items in the second subcomponent highlight the relevance of the English language and English classes, lack of practicability of the language, difficulty of learning English, and the student's low self-esteem while learning English. Thus, it was suitable to name it Lack of Interest towards the English language and English Classes. Inadequate usage of instructional technologies, not checking the materials handed out in class, and not having a student-centered classroom environment are the statements in the third subcomponent. Therefore, it was named Class Environment and Class Materials. Since the fourth subcomponent covers factors of failure during the student's learning progress, it was named Experience of Failure.

Each item's score in the scale ranges from 0 (never affects) to 5 (affects a lot), which shows the degree of demotivation of the student relating to the item. The overall score of the scale is obtained via the sum of the scores of each item. When the overall score of the scale is considered, the degree of demotivation is directly proportional. The higher the score the students get, the more demotivated they are. That is, zero (0) means that the students face no factors which demotivate them and they are motivated to learn English. Unlike this, the score 100 indicates that the students are highly demotivated towards the English language and English classes, which hinders their learning. The scores of the subcomponents of the scale show how much that factor demotivates students in their learning process.

The scores to be obtained from the 20 -item demotivation scale in general range from zero to 100 . The lowest score obtained from the data collected from 454 students is zero and the highest score is 100 . Therefore, the overall scores obtained cover the whole range of the scale.

\section{Reliability of the Scale}

Cronbach Alpha coefficient for the reliability of the scale was 0.911. Cronbach Alpha coefficients for the subcomponents were $0.847 ; 0.813 ; 0.780$ and 0.768 respectively. These scores show that Cronbach Alpha coefficient for the reliability of the scale is quite high. These results can be regarded as an indicator that the scale is reliable.

\section{Validity of the Scale}

In order to have supporting evidence for the construct validity of the one factorfour subcomponent structure found after EFA with Promax rotation method, the CFA was done. The CFA on the same data revealed the same structure. It revealed that all factor loads were statistically significant $(\mathrm{p}<0.05)$. Fit indexes were RMSEA $=0.060$; $\mathrm{CFI}=0.93 ; \mathrm{GFI}=0.91 ; \mathrm{AGFI}=0.89 ; \mathrm{SRMR}=0.048$. These findings suggest that the model fitness was provided. Chi-squared statistics $\left(\mathrm{X}^{2}=429.33\right.$; $\left.\mathrm{DF}=164\right)$ were found to be statistically significant and $\mathrm{X}^{2} / \mathrm{df}$ was calculated as 2.61 . This result proves that the model has an acceptable goodness of fit index. 
Another evidence for the construct validity can be the discriminatory nature of the scale. That is, the scale could discriminate the known groups in terms of low correlation with instruments measuring a different construct; or differences between known groups (Aiken, 1996; Tezbaşaran, 2008). So, in order to see if the scale has a discriminatory nature, the gender variable was chosen to test the data because the demotivating factors for female and male students were found to be different in the literature (Muhonen, 2004; Kaivanpanah \& Ghasemi, 2011).

Independent samples t-test analysis was used to find out whether the demotivation levels of the students towards the English language and English classes show any differences according to their gender. The results of the analysis showed that the mean score of the female students $(n=229)$ in all sub-components of the scale seems to be higher than that of the male students $(n=225)$. Yet, when the significant levels of each sub-component of the scale were considered, it showed that, unlike the "characteristics of teacher" $\left(\mathrm{t}_{452}=1.653 ; \mathrm{p}=.099>.05\right)$ and "lack of interest towards the English language and English classes" $\left(\mathrm{t}_{452}=.229 ; \mathrm{p}=.819>.05\right)$ sub-components, female students were significantly more demotivated than male students in terms of "class environment and class materials" $\left(\mathrm{t}_{452}=2.275 ; \mathrm{p}=.023<.05\right)$ and "experience of failure" $\left(\mathrm{t}_{452}=2.253 ; \mathrm{p}=.025<.05\right)$ sub-components of the scale. In her study, Muhonen (2004) found that while male students were more demotivated by the characteristics of the teacher, female students were more demotivated by the learning materials. In addition, Kaivanpanah and Ghasemi (2011) highlighted in their study that female students were more demotivated by the characteristics of the teacher and experience of failure than male students were. Therefore, in light of these findings, the scale can be said to have a discriminative nature.

\section{Discussion and Conclusion}

In this study, 454 university students in the English preparatory school completed a 50-item scale prepared to identify the factors affecting the university students' demotivation levels towards the English language and English classes. Reliability and validity of the scale were analyzed. Via the item analysis based on Pearson correlation, the items whose correlation coefficient was not zero were omitted from the scale and the factor load of 20-item scale was examined.

The EFA, using the Promax rotation method, gave a structure of one factor including four subcomponents with 20 items. These subcomponents were named as Teacher Characteristics, Lack of Interest towards the English language and English Classes, Class Environment and Class Materials and Experience of Failure respectively.

Sakai and Kikuchi (2009) identified six major factors (teachers, experience of failure, characteristics of classes, class environment, class materials, and lack of interest) after the revision of a number of locally published studies of demotivation in the Japanese EFL context. Besides, Dörnyei (in Dörnyei \& Ushioda, 2011, pp. 150-151) also discusses these categories under which he seemingly lists his nine categories as examples. 
When we compare the findings with Sakai and Kikuchi's (2009) six major categories of demotivation, the demotivating factors (Teacher Characteristics, Lack of Interest towards the English language and English Classes, Class Environment and Class Materials, and Experience of Failure) found in this study overlap with Sakai and Kikuchi's list with some differences. For instance, while Sakai and Kikuchi (2009) identified "class environment", "class materials" and "characteristics of classes" as different demotivating factors, these factors were found in the same category named as "Class Environment and Class Materials" in this study.

Moreover, when the results of the studies done in other countries were compared with this study, factors such as "interference of another foreign language being studied" (Dörnyei, 1998 in Dörnyei \& Ushioda, 2011), "punishments" (Chang \& Cho, 2003), "grammar-translation" (Falout et al., 2009; Kikuchi, 2009), "simultaneous learning of other languages" (Alavania \& Sehat, 2012), "focus on difficult grammar" (Ghadirzadeh, Hashtroudi, \& Shokri, 2012) and "attitudes towards English speaking community" (Dörnyei, 1998 in Dörnyei \& Ushioda, 2011; Falaut \& Maruyama, 2004; Kaivanpanah \& Ghasemi, 2011 ) were not seen in this study. This may be attributed to the fact that these factors can be peculiar to the English-language learning context in the countries (and even in the very schools) the studies were conducted (Sakai \& Kikuchi, 2009).

The fact that the Cronbach Alpha coefficient for the reliability of the scale was 0.911 and that the Cronbach Alpha coefficients for the subcomponents were 0.847; $0.813 ; 0.780$; and 0.768 , respectively reveal that the scale as a whole and each of the subcomponents of the scale in itself carry out reliable measurement.

CFA was used for the construct validity of the scale. The CFA result shows that the data correspond with the model obtained. This finding confirms the conclusion that the scale has a structure of one factor (one factor with four subcomponents). The high correlation between the subcomponents also supports the fact that the scale has one factor.

In order to have further supporting evidence for the construct validity of the scale, an analysis whether there are any differences according to gender was done. When the subcomponents of the scale were considered, while there was no significant difference in characteristics of teacher and lack of interest towards the English language and English classes subcomponents of the scale regarding the gender, a significant difference in experience of failure and class environment and class materials subcomponents of the scale was observed. Kaivanpanah and Ghasemi (2011), in their study, highlighted that there was significant difference in characteristics of teacher and experience of failure subcomponents, but not in class environment and lack of interest subcomponents regarding the gender. Meshkat and Hassani (2012) reported, in their study, a significant difference in learning contents and materials and teachers' competence and teaching styles in relation to gender of the students.

For the validation of the structure obtained in EFA, CFA was initiated using the same data set. Yet, the validation of the structure should be tested using different data sets (samples) to obtain supportive evidence for it. 
This study was conducted only on the students taking English preparatory class at the school of foreign languages. Therefore, it is recommended that the factors demotivating the students at other faculties towards the English language and English classes also be studied. Another recommendation is that this very scale prepared for university students is applied on those attending primary and secondary education as well.

\section{References}

Aiken, L. R. (1996). Rating Scales \& Checklists. Evaluating Behavior, Personality and Attitudes. USA: John Wiley \& Sons, Inc.

Alavinia, P., \& Sehat, R. (2012). A Probe into the Main Demotivating Factors among Iranian EFL Learners. English Language Teaching, 5(6), 9-35. http://dx.doi.org/10.5539/elt.v5n6p9

Bekleyen, N. (2011). Demotivating factors in the EFL environment. E-proceedings of the International Online Language Conference, 1(2), 151-156.

Büyüköztürk, Ș. (2007). Deneysel Desenler: Öntest-Sontest Kontrol Grubu Desen ve Veri Analizi $\left(2^{\text {nd }}\right.$ Ed.). Ankara: Pegem A Yayıncılık.

Chang, S. M., \& Cho, C. H. (2003). Demotivating Factors in Foreign Language Learning. Selected Papers from the Twelfth International Symposium on English Teaching (pp. 257-264). Taipei: Crane Publishing.

Çokluk, Ö., Şekercioğlu, G., \& Büyüköztürk, Ş. (2010). Sosyal Bilimler İçin Çok Değişkenli İstatistik: SPSS ve LISREL Uygulamaları. Ankara: Pegem A Yayıncılık.

Dörnyei, Z., \& Ushioda, E. (2011). Teaching and Researching Motivation (2 ${ }^{\text {nd }}$ Ed.). Harlow: Longman.

Erkuş, A. (2003). Psikometri Üzerine Yazılar. Ankara: Türk Psikologlar Derneği Yayınları.

Falout, J., \& Maruyama, M. (2011). A Comparative Study of Proficiency and Learner Demotivation. The Language Teacher, 28(8), 3-9 /online/. Retrieved on April $13^{\text {th }} 2012$ from http://jalt-publications.org/tlt/articles/447-comparative-study-proficiency-andlearner-demotivation.

Falout, J., Elwood, J., \& Hood, M. (2009). Demotivation: Affective states and learning outcomes. System, 37(3), 403-417. http://dx.doi.org/10.1016/j.system.2009.03.004

Field, A. P. (2009). Discovering statistics using SPSS (3 ${ }^{\text {rd }}$ Ed.). London: Sage Publications.

Ghadirzadeh, R., Hashtroudi, F., \& Shokri, O. (2012). Demotivating Factors for English Language Learning Among University Students. Journal of Social Sciences, 8(2), 189-195.

Kaivanpanah, S., \& Ghasemi, Z. (2011). An Investigation into Sources of Demotivation in Second Language Learning. Iranian Journal of Applied Linguistics (IJAL), 14(2), 89-110. 
Kalaycı, Ş. (2005). SPSS Uygulamalı Çok Değişkenli İstatistik Teknikleri. Ankara: Asil Yayın Dağıtım.

Kikuchi, K., \& Sakai, H. (2009). Japanese learners' demotivation to study English: A survey study. JALT Journal, 31(2), 183-204.

Kikuchi, K. (2009). Listening to our learners' voices: what demotivates Japanese high school students? Language Teaching Research, 13(4), 453-471. http://dx.doi. org/10.1177/1362168809341520

Köklü, N. (2002). Açıklamalı İstatistik Terimleri Sözlü̈̆̈̈. Ankara: Nobel Yayın Dağıtım.

Martin, C. R., \& Newell, R. J. (2004). Factor Structure of the Hospital Anxiety and Depression scale in Individuals with Facial Disfigurement. Psychology Health and Medicine, 3, 327336. http://dx.doi.org/10.1080/13548500410001721891

Meshkat, M., \& Hassani, M. (2012). Demotivating factors in learning English: the case of Iran. Procedia - Social and Behavioral Sciences, 31, 745-749. http://dx.doi.org/10.1016/j. sbspro.2011.12.134

Muhonen, J. (2004). Second language demotivation: factors that discourage pupils from learning the English language (Unpublished master's thesis). Jyväskylä, Finland: UNiversity of Jyväskylä..

Sakai, H., \& Kikuchi, K. (2009). An analysis of demotivators in the EFL classroom. System, 37(1), 57-69. http://dx.doi.org/10.1016/j.system.2008.09.005

Scarcella, R., \& Oxford, R. L. (1992). The Tapestry of Language Learning: The Individual in the Communicative Classroom. Boston: Heinle \& Heinle.

Schriesheim, C. A., \& Eisenbach, R. J. (1995). An Exploratory and Confirmatory Factor Analytic Investigation of Item Wording Effects on Obtained Factor Structures of Survey Questionnaire Measures. Journal of Management, 21(6), 1177-1193. http://dx.doi. org/10.1177/014920639502100609

Shevlin, M. E., \& Lewis, C. A. (1999). The Revised Social Anxiety Scale: Exploratory and Confirmatory Factor Analysis. The Journal of Social Psychology, 139(2), 250-252.

Spolsky, B. (1989). Conditions for Second Language Learning. Oxford: Oxford University Press. http://dx.doi.org/10.1080/00224549909598381

Tabachnick, B. G., \& Fidell, L. S. (2001). Using Multivariate Statistics. New York: Allyn \& Bacon Inc.

Tatlıdil, H. (1992). Uygulamalı Çok Değişkenli İstatistiksel Analiz. Ankara: Engin Yayınları.

Tavşancıl, E. (2006). Tutumların Ölçülmesi ve SPSS ile Veri Analizi. Ankara: Nobel Yayın Dağıtım.

Tezbaşaran, A. (2008, January). Likert Tipi Ölçek Hazırlama Klavuzu /online/. Retrieved on March 13 $3^{\text {th }} 2014$ from http://www.akademia.edu/1288035/Likert_Tipi_Ölçek_Hazırlama_ Klavuzu

Trang, T., \& Baldauf, R. B. (2007). Demotivation: Understanding Resistance to English Language Learning - The Case of Vietnamese Students. The Journal of Asia TEFL, 4(1), 79-105.

Ushioda, E. (2008). Motivation and good language learners. In C. Griffiths (Ed.), Lessons from good language learners (pp. 19-34). Cambridge: Cambridge University Press. http:// dx.doi.org/10.1017/CBO9780511497667.004 


\author{
Kerim Unal \\ ELT Department \\ Faculty of Education \\ Mersin University \\ Çiftlikköy Kampusu 33343 Yenisehir / Mersin, Turkey \\ kerimunal73@gmail.com
}

\title{
Tugba Yanpar Yelken
}

Curriculum Development and Instruction Department

Faculty of Education

Mersin University

Çiftlikköy Kampusu 33343 Yenisehir / Mersin, Turkey

tyanpar@gmail.com

\section{Appendix}

\section{Appendix A}

\section{English version of the English Demotivation Scale}

Demotivation is the condition where the motivational basis of a behavioral intention or an ongoing action of the person is reduced, or diminished by specific external forces. Below are given some situations which are thought to affect your motivation on learning English. Please, read these statements carefully considering your motivation on learning and mark the suitable box which shows the degree to which a particular situation affects your motivation ADVERSELY.
No vocabulary is taught in English classes (8)

I get lower marks in English exams (10)

Only the teacher speaks in English classes (16)

I am not as successful as the other students in English exams (17)

Audio equipment (CD, tape, etc.) is not employed in English classes (18)

The materials handed out are not reviewed in class (19)

Various activities related to the topic being covered are not done (23)

I am only unsuccessful in English classes (24)

I think English classes are unnecessary (27)

I think learning English is too difficult (28)

The teacher always compares the students (29)

I have no interest in English (34)

I think I have no talent / abilities for learning English (35)

The teacher has a bad English pronunciation (36)

The teacher does not pay attention to me in class (37)

The teacher gives wrong information about the topic under study (40)

I think studying English is a waste of time (42)

The teacher prejudices the students against English (44)

The teacher makes fun of the students' mistakes (47)

The reason why I come to school / have education is not to learn English only (50)
The degree to which my motivation for learning English is affected ADVERSELY

\begin{tabular}{|c|c|c|c|}
\hline 4 & 3 & 2 & 1 \\
\hline 4 & 3 & 2 & 1 \\
\hline 4 & 3 & 2 & 1 \\
\hline 4 & 3 & 2 & 1 \\
\hline 4 & 3 & 2 & 1 \\
\hline 4 & 3 & 2 & 1 \\
\hline 4 & 3 & 2 & 1 \\
\hline 4 & 3 & 2 & 1 \\
\hline 4 & 3 & 2 & 1 \\
\hline 4 & 3 & 2 & 1 \\
\hline 4 & 3 & 2 & 1 \\
\hline 4 & 3 & 2 & 1 \\
\hline 4 & 3 & 2 & 1 \\
\hline 4 & 3 & 2 & 1 \\
\hline 4 & 3 & 2 & 1 \\
\hline 4 & 3 & 2 & 1 \\
\hline 4 & 3 & 2 & 1 \\
\hline 4 & 3 & 2 & 1 \\
\hline 4 & 3 & 2 & 1 \\
\hline 4 & 3 & 2 & 1 \\
\hline
\end{tabular}




\section{Demotiviranost turskih učenika za učenje engleskoga jezika: razvijanje mjerne skale}

\section{Sažetak}

Svrha je ovoga istraživanja razviti skalu koja će otkriti faktore koji negativno utječu na motiviranost za engleski jezik $i$ učenje engleskoga kod studenata $u$ pripremnoj fakultetskoj nastavi. Uzorak je činilo 454 učenika. Istraživači su se koristili Likertovom skalom od 6 stupnjeva s 50 čestica kako bi došli do podataka. Rezultati deskriptivne faktorske analize ukazali su na to da skala ima jedan faktor $s$ četiri podkomponentnom faktorskom strukturom od 20 čestica. Podkomponente skale su: 1) Karakteristike nastavnika, 2) Nedostatak interesa prema engleskome jeziku i učenju engleskoga jezika, 3) Razredno okruženje i nastavni materijali i 4) Doživljaj neuspjeha. Cronbachov alfa koeficijent za pouzdanost skale bio je 0,911. Cronbachov alfa koeficijenti za podkomponente bili su: 0,847; 0,813; 0,780 i 0,768. Rezultati CFA ukazali su na to da faktorska struktura odgovara podacima. Skala je pouzdan i valjan instrument za mjerenje faktora demotivacije učenika u procesu učenja jezika.

Ključne riječi: demotivacija; faktori demotivacije; skala demotivacije; ELT; pripremna nastava jezika.

\section{Uvod}

Motivacija je jedan od ključnih faktora koji utječu na proces učenja jezika i ima izravan učinak na učenikov trud, primjenu potrebnih strategija učenja, spremnost za korištenje ciljnoga jezika i na uspjeh u školskim ispitima (Scarcella i Oxford, 1992 ; Spolsky, 1989)). Zbog toga da bi učenici bili uspješni u učenju ciljnoga jezika, ključno je da su visoko motivirani. Međutim, motivacija učenika podložna je mnogim negativnim utjecajima dok traje proces učenja ciljnoga jezika (Dörnyei i Ushioda, 2011; Falout, Elwood, i Hood, 2009; Falout i Maruyama, 2004; Kikuchi, 2009; Kikuchi i Sakai, 2009). Ti utjecaji umanjuju njihovu motivaciju na početku procesa učenja jezika. Dörnyei to naziva demotivacija, tj. 'specifične vanjski sile koje snižavaju ili umanjuju motivacijsku osnovu namjere ponašanja ili kontinuiranoga rada' (Dörnyei i Ushioda, 2011, str. 139). Štoviše, Dörnyei i Ushioda (2011, str. 138) identificirali su tri situacije u kojima negativni faktori utječu na motivaciju učenika. Prvi faktor čine situacije 
povezane s učenjem, ili iskustvo, poput tjeskobe kod uspjeha, društveni pritisak, veliko radno opterećenje ili loši rezultati u testovima. Druge su situacije povezane s faktorima u okruženju društvenog učenja. Ti faktori mogu biti pritisak vršnjaka, osobnost, stavovi vršnjaka ili nastavnika. Treća situacija odnosi se na društveni kontekst izvan razrednog okruženja u kojem razgovor i stavovi zajednice mogu ometati proces učenja jezika.

Međutim, kako tvrde Dörnyei i Ushioda (2011), ne utječu svi događaji u takvim situacijama na motiviranost učenika. Ako učenici imaju jake distraktore koji nemaju negativnu vrijednost, ako postupno gube interes, ili odjednom shvate koliko je utrošak rada koji su odlučili slijediti, takve situacije ne možemo uvrstiti u faktore demotivacije.

Demotivacija ima negativan učinak na proces učenja jezika i na njihove ishode. Ona negativno utječe na stavove i ponašanje učenika prema engleskome jeziku, nastavu engleskoga jezika ili nastavnika jezika, pa tako ometa motivaciju nastavnika i dinamiku skupine. Demotivacija donosi široke i dugoročne negativne ishode učenja (Falout i sur., 2009). Jednom demotivirani, učenici se suočavaju s poteškoćama u učenju ciljnoga jezika zbog čega im proces učenja postaje manje ugodan. Dostizanje očekivanih ishoda učenja u konačnici postaje sve teže (Falout i sur., 2009).

Prema tome, za stvaranje uspješnog okruženje za učenje nastavnici moraju neprestano osluškivati motivaciju svojih učenika te pokušati otkriti faktore demotivacije i ukloniti ih.

Postoji nekoliko studija u literaturi koje su usredotočene na otkrivanje faktora koji demotiviraju učenike u procesu učenja jezika. Dörnyei (1998; u Dörnyei i Ushioda, 2011) su proveli 10 do 30-minutni strukturirani intervju s 50 demotiviranih učenika koji su učili engleski ili njemački jezik u Budimpešti, u Mađarskoj. Identificirano je devet faktora demotivacije: 1) nastavnik, 2) neodgovarajući školski prostor, 3) smanjeno samopouzdanje, 4) negativan stav prema L2 (drugome jeziku), 5) obaveza učenja L2, 6) upletanje drugoga stranoga jezika koji se uči istodobno, 7) negativan stav prema zajednici L2, 8) stavovi članova skupine i 9) udžbenik. Otkrio je da su faktori nastavnik i smanjeno samopouzdanje više demotivirajući od ostalih spomenutih faktora.

Nakon intervjuiranja 20 irskih studenata koji su učili francuski, Ushioda (1998) je primijetio da su negativni aspekti školskog okruženja poput korištenja određenim nastavnim metodama demotivirajući faktori za studente.

Chang i Cho (2003) napravili su analizu sadržaja sastava koje su prikupili od 91 tajvanskog učenika viših razreda osnovne škole. Nakon analize ukazali su na osam faktora demotivacije: 1) poteškoće u učenju, 2) prijetnje samodostojanstvu, 3) monotono poučavanje, 4) loši odnosi nastavnika i učenika, 5) kazne, 6) anksioznost - opća i jezično specifična, 7) nedostatak odlučnosti i 8) loše upravljanje razredom. $\mathrm{U}$ drugome istraživanju u kojemu su učenici pisali sastave o faktorima koji ih demotiviraju Muhonen (2004) je radio s 91 učenikom devetih razreda te je identificirao pet faktora demotivacije: 1) nastavnik, 2) materijal za učenje, 3) karakteristike učenika, 4) školsko okruženje i 5) stavovi učenika prema engleskome jeziku. 
Trang i Baldauf (2007) zatražili su od 100 studenata na sveučilištu da napišu sastav o faktorima koji ih demotiviraju. Iznjedrili su 14 demotivirajućih kategorija koje su klasificirali u dvije skupine: 1) unutarnja svojstva (poput stavova prema engleskome jeziku, doživljaj neuspjeha, samopoštovanje) i 2) vanjska svojstva (nastavnik, okruženje u kojemu se uči, neprikladno radno opterećenje itd.).

Falout i Maruyama (2004) proučavali su odnos između učeničkog znanja jezika i demotivacije. Za potrebe istraživanja razvili su upitnik od 49 čestica na osnovi devet faktora demotivacije. Dörnyei i Ushioda (2011) identificirali su i administrirali upitnik nad 164 studenta u dva prirodoslovna odjela. Prema dobivenim rezultatima, identificirali su šest faktora demotivacije: 1) nastavnik, 2) sati, 3) stavovi prema engleskoj govornoj zajednici, 4) stavovi prema engleskome jeziku, 5) samopouzdanje i 6) stavovi prema članovima skupine. Naglasili su da studenti niže razine znanja identificiraju samopouzdanje, stavove prema nastavi L2, nastavnike i stavove prema članovima skupine kao faktore najviše demotivacije, a studenti više razine znanje identificiraju samopouzdanje kao najvažniji faktor demotivacije.

Kako bi identificirao faktore demotivacije kod japanskih srednjoškolaca, Kikuchi (2009) je pitao pet studenata privatnih i javnih sveučilišta da podijele svoje iskustvo u srednjoj školi vezano uz nastavu engleskoga jezika. Četrdeset i dva studenta s javnih sveučilišta ispunila su pitanja otvorenoga tipa koja su pripremljena nakon intervjua. Nakon analize sadržaja, identificirani su sljedeći faktori demotivacije: 1) ponašanje nastavnika, 2) gramatičko-prijevodna metoda, 3) testovi i prijemni ispiti, 4) memoriranje vokabulara i 5) udžbenici i referentna literatura. Tradicionalna metodika i ponašanje nastavnika istaknuli su se kao faktori demotivacije $\mathrm{u}$ japanskom kontekstu.

Nakon što su proučili prijašnja istraživanja vezana uz demotivaciju učenika, Sakai i Kikuchi (2009) identificirali su nastavnike, karakteristike razreda, doživljaj neuspjeha, razredno okruženje, materijale za nastavu i nedostatak interesa kao glavne čimbenike demotivacije. Oni su pripremili upitnik s 35 čestica te ga podijelili 656 japanskih učenika srednjih škola. Identificirali su sadržaj učenja i materijale, kompetentnost nastavnika i stil poučavanja, neadekvatan školski prostor, nedostatak intrinzične motivacije i uspjeh na testovima kao izvore demotivacije.

U drugome istraživanju nad japanskim učenicima Falout i sur. (2009) razvili su i podijelili upitnik od 52 čestice japanskim studentima (900) koji su studirali poučavanje engleskoga jezika. Prema dobivenim podacima, identificirali su devet čimbenika demotivacije (nastavnik, traženje pomoći, traženje zadovoljstva, gramatičkoprijevodna metoda, izbjegavanje, samoocrnjivanje, vrijednost i razina kolegija), koji se razlikuju od prethodno spomenutih.

Osim istraživanja demotivacije u japanskom kontekstu postoje i četiri istraživanja iz iranskog konteksta. Isprva su Kaivanpanah i Ghasemi (2011) proveli istraživanje nad 327 učenika viših razreda osnovne škole, srednje škole i studenata na fakultetu, te su identificirali pet čimbenika demotivacije (nastavnik, stav prema učenju drugoga jezika, stav prema engleskoj govornoj zajednici, učenje sadržaja, materijali, školski objekti i doživljaj neuspjeha) iz podataka dobivenih putem upitnika od 32 čestice. 
Zatim su Meshkat i Hassani (2012) iskoristili upitnik od 21 čestice kako bi dobili podatke od iranskih srednjoškolca (429), te su otkrili sljedeće čimbenike demotivacije: neadekvatni školski prostori, učenje sadržaja i materijali, kompetencije i stilovi poučavanja, nedostatak intrinzične motivacije, rezultati na ispitima.

Nadalje, Alavania i Sehat (2012) upotrijebili su upitnik od 50 čestica te ga proveli nad iranskim srednjoškolcima (165) kako bi identificirali čimbenike demotivacije. Oni su istaknuli devet čimbenika demotivacije učenika u procesu učenja engleskoga kao drugoga jezika: 1) okruženje za učenje, 2) istodobno učenje drugih jezika, 3) materijal za učenje i predmetni sadržaj, 4) metoda poučavanja, 5) iskustvo neuspjeha, 6) nedostatak uspjeha, 7) osobnost i ponašanje nastavnika, 8) karakteristike učenika, 9) stavove.

Ghadirzadeh, Hashtroudi i Shokri (2012) proveli su s iranskim studentima (260) upitnik od 35 čestica koji su pripremili Sakai i Kikuchi (2009) te su pronašli pet čimbenika demotivacije: 1) nedostatak uviđanja individualne kompetencije, 2) nedostatak intrinzične motivacije, 3) neprikladne karakteristike nastavnikovih metoda poučavanja i sadržaj predmeta, 4) neprikladni uvjeti fakultetima i 5) usredotočenost na tešku gramatiku.

Kada se spominju istraživanja vezana uz faktore demotivacije u turskom kontekstu, postoji jedno istraživanje na uzorku od 74 studenta koje je proveo Bekleyen (2011). U tom istraživanju Bekleyen (2011) je identificirao 8 faktora demotivacije iz podataka koje je dobio iz upitnika koji se sastojao od 11 čestica, a izrađen je prema Dörnyeovoj devet-faktorskoj klasifikaciji. Faktori demotivacije bili su: 1) nastavnici, 2) školski sadržaji, 3) iskustvo studenata, odnosno neuspjeh ili uspjeh, 4) stavovi prema engleskome jeziku, 5) obvezatna priroda engleskoga jezika, 6) negativan stav prema govornicima engleskoga jezika, 7) stavovi vršnjaka i 8) udžbenici.

Proučavajući istraživanja navedena u literaturi, opazili smo da se njihov poredak prema važnosti i sami faktori demotivacije razlikuju od zemlje do zemlje, razreda i vrste škole. U usporedbi s drugim zemljama, u Turskoj ne postoji puno istraživanja demotiviranosti. Zbog toga je cilj bio izraditi skalu demotivacije za predmet engleski kao strani jezik koji bi pomogao u otkrivanju onih faktora koji demotiviraju učenike u procesu učenja jezika.

Očekuje se da će razvoj skale značajno doprinijeti ovome području. Uz podatke koji će biti dobiveni skala može pomoći i školskoj administraciji kao i nastavnicima engleskoga jezika u otkrivanju razloga koji utječu na uspješnost učenika i razinu interesa. Drugim riječima, osvijetlit će faktore koji pojačavaju razinu demotiviranosti učenika i razviti metode koje će te faktore eliminirati.

\section{Metode}

S obzirom na to da je cilj ovoga istraživanja razviti skalu koja naglašava faktore koji negativno utječu na motivaciju učenika u pripremnoj nastavi engleskog jezika, može se reći da ovo istraživanje posjeduje karakteristike kvalitetnoga istraživačkoga rada. 


\section{Uzorak}

Podaci u ovome istraživanju dobiveni su od 454 studenta koji su pohađali nastavu engleskoga jezika u Školi stranih jezika pri Sveučilištu Mersin. 60,1 \% sudionika $(\mathrm{n}=273)$ nalazilo se na osnovnoj razini; $36,3 \%(\mathrm{n}=165)$ na nižem srednjem stupnju; $3,5 \%(n=16)$ na višem srednjem stupnju. 50,4 \% sudionika bile su žene $(n=229)$, a 49,6 \% ( $n=225)$ muškarci. Podaci otkrivaju da je $80 \%$ studenata $(n=363)$ imalo 20 ili manje godina; $17 \%(n=77)$ između 21 i $26 ; 3,1 \%(n=14) 27$ i više godina.

\section{Instrument}

U prvoj fazi razvijanja skale zatražili smo od 30 studenata prve godine da napišu referat o pozitivnim i negativnim faktorima s kojima su se susreli u procesu učenja jezika, a zatim posljedice tih faktora na njih same. Koristeći se podacima iz tih referata i povezane literature, pripremljen je obrazac od 65 čestica, koje se smatralo indikatorima faktora koji utječu na razinu demotiviranosti studenata prema engleskome jeziku i nastavi engleskoga jezika.

U sljedećoj fazi devet stručnjaka iz područja: praćenje i vrednovanje (2), izrada i razvoj kurikula (3), poučavanje engleskoga jezika (2), psihološko savjetovanje i vođenje (2) zamoljeno je da rangiraju svaku česticu na skali od jedan do deset kako bi se pokazalo koliko je povezana s kontekstom.

U posljednjoj fazi zbrojene su ocjene za svaku česticu i dobivena je srednja ocjena. Ukupno 15 čestica čija je srednja ocjena bila manja od 6,0 izostavljeno je iz obrasca. Pripremljen je pilot -obrazac od 50 čestica koristeći se Likertovom skalom od 6 stupnjeva kod koje 5 - „ima veliki utjecaj“ do 0 - „nema nikakav utjecaj“. Pilot-upitnik ispunilo je ukupno 467 studenata iz Škole za strane jezike pri Sveučilištu Mersin. Trinaest upitnika isključeno je iz analize jer nisu bili ispunjeni u cijelosti.

\section{Analiza podataka}

Korelacijska matrica podataka prikupljena od 454 studenta Škole stranih jezika je skenirana. Kod skeniranja korelacijske matrice pretpostavili smo da je rezultat korelacije viši od 0,3, a razina značajnosti 0,000 (Field, 2009). Prema tome, čestice koje su imale korelaciju manju od 0,3 , a razinu značajnosti veću od 0,000 bile su isključene iz obrade. Nakon toga, primijenjena je eksplorativna faktorska analiza (EFA) kako bi se odredila valjanost konstrukta. Za identificiranje čestica za skalu uzeli smo u obzir sljedeće kriterije: 1) Eigen vrijednost najmanje 1,00 (Shevin i Lewis, 1999); 2) faktorsko opterećenje najmanje 0,30 (Martin i Newel, 2004; Schriesheim i Eisenbach, 1995); 3) sve čestice u jednom faktoru i 4) postojanje najmanje 0,10 razlike između faktorskih opterećenja čestica u dva faktora (Büyüköztürk, 2007).

Kako bi se otkrilo jesu li podaci odgovarajući za faktorsku analizu, razmotreni su rezultati Bartlettova testa i Kaiser-Meyer-Olkin (KMO) testa. (Kalayc1, 2005; Tavşancıl, 2006). S obzirom na to da je korelacija čestica skale i alfa koeficijent visoka $(\alpha=0,924)$, te se smatralo da postoji povezanost između faktora, odlučeno je da se koristi Promax 
rotacija koja je jedna od metoda koja se koristi za rotaciju kako bi se jasno uočila distribucija faktorskog opterećenja (Tatlıdil, 1992; Erkuş, 2003).

Čestice s faktorskim opterećenjem manjim od 0,30 , i one koje postoje u više od jednog faktora, izostavljene su jedna po jedna, a faktorska analiza ponovljena je nakon izostavljanja svake čestice (Çokluk, Şekercioğlu, i Büyüköztürk, 2010). Analiza je provedena na faktorima čija je Eigen vrijednost bila veća od 1,00 (Çokluk i sur., 2010; Köklü, 2002; Tabachnick i Fidell, 2001).

Za dobivanje dokaza o valjanosti konstrukta jednog faktora s četiri podkomponente uočene nakon faktorske analize korištenjem metode Promax rotacije, te slaganje ove strukture s podacima, napravljena je konfirmatorna faktorska analiza (CFA) na istom skupu podataka. Statistika Hi-kvadrata $\left(\mathrm{X}^{2}\right)$, srednja kvadratna pogreška aproksimacije (RMSEA), usporedni indeks pristajanja (CFI), indeks najboljeg pristajanja (GFI), prilagođeni indeks najboljeg pristajanja (AGFI) i standardizirani rezidualni srednji kvadratni korijen (SRMR) koristili su se za određivanje valjanosti strukture.

Pouzdanost završne skale i skale podkomponenti dobiveni su Cronbachov Alfa koeficijentom pouzdanosti. Za dobivanje potvrdnih dokaza o valjanosti konstrukta skale analizirano je pokazuje li rezultat skale razliku u odnosu na varijable spol, dob, fakultet ili jezičnu razinu. Pokazuje li zavisna varijabla normalnu distribuciju na razinama zavisne varijable provjerena je testovima normalnosti. T-test upotrijebljen je za analizu razlika s obzirom na spol, jednosmjerna ANOVA analiza koristila se za provjeru razlika s obzirom na dob, fakultet $\mathrm{i}$ jezičnu razinu. Za faktorsku analizu te analizu valjanosti i pouzdanosti koristili su se SPSS 20 i LISREL 8.50 programi.

\section{Rezultati}

\section{Analiza čestica}

$\mathrm{U}$ analizi čestica utemeljenoj na korelaciji identificirane su čestice čiji koeficijent korelacije nije bio nula i te su čestice izostavljene iz skale.

\section{Analiza faktorske strukture skale}

$S$ obzirom na rezultat Bartlettova testa sferičnosti analiza prikladnosti skale od 20 čestica za faktorsku analizu Hi-kvadrat statistika je značajna $\left(X^{2}=3621,168\right.$, $\mathrm{p}<0,05)$, a KMO rezultat je izvrstan $(0,924>0,50)$. Ta dva rezultata pokazala su da je skup podataka podoban za provođenje faktorske analize. Rezultati osnovne analize komponenti, prije rotacije, ukazuju na postojanje četiri faktora čije su Eigen vrijednosti veće od 1,00 . Ukupna varijanca za ta četiri faktora je $57,857 \%$, a ukupna varijanca za svaki faktor bila je 37,461 \%; 8,452 \%; 6,772 \% i 5,172 \%. Osim toga Eigen vrijednosti za svaki od faktora bile su 7,492; 1,690; 1,354; i 1,034. Cronbachov alfa koeficijent za pouzdanost skale bio je 0,920 .

S obzirom na činjenicu da su gotovo sve čestice u prvom faktoru te da je korelacija čestica kao i Cronbachov alfa koeficijent visoka, zaključeno je da postoji povezanost 
među faktorima. Zbog toga je faktorska analiza ponovljena korištenjem metode Promax rotacije, te je dobivena struktura od četiri faktora s 20 čestica. Ukupna varijanca četiri faktora objašnjava $57,857 \%$, a ukupna varijanca svakog faktora posebno objašnjava $37,461 \% ; 8,452 \% ; 6,772 \%$ i 5,172 \%. Uočeno je da je Eigen vrijednost za prvi faktor $(7,492)$ gotovo pet puta veća od Eigen vrijednosti za drugi faktor $(1,690)$. Iz toga možemo zaključiti da skala ima zajednički faktor $s$ obzirom na visinu ukupne objašnjene varijance u prvom faktoru i razlika Eigen vrijednosti između prvoga i drugoga faktora. Prema tome, skala ima jednofaktorsku strukturu s četiri podkomponente. Tablica 2 pokazuje rezultate Promax rotacije.

\section{Tablica 1}

Kao što pokazuje Tablica 1 postoji šest čestica u prvoj i drugoj podkomponenti, pet čestica u trećoj i tri čestice u četvrtoj podkomponenti. Kada analiziramo čestice u prvoj podkomponenti, vidi se kako daju utočište faktorima demotiviranosti koji su povezani s osobnošću nastavnika, jezikom i vještinom poučavanja, i stavovima prema studentima. Zbog toga je podkomponenta nazvana Karakteristike nastavnika. Čestice u drugoj podkomponenti naglašavaju važnost engleskoga jezika i nastave engleskoga jezika, nedostatak upotrebe jezika, teškoće u učenju engleskoga jezika, te vrlo nisko samopoštovanje studenata kod učenja engleskoga jezika. Stoga je tu podkomponentu bilo prikladno nazvati Nedostatak interesa prema engleskome jeziku i nastavi engleskoga jezika. Nedovoljno korištenje tehnologija poučavanja, neprovjeravanje materijala koji su odrađeni na nastavi, nepostojanje okruženja koje je orijentirano na studenta neke su od izjava vezanih uz treću podkomponentu. Ona je naslovljena Razredno okruženje i nastavni materijali. S obzirom na to da četvrta podkomponenta pokriva faktore neuspjeha u procesu učenja, nazvana je Doživljaj neuspjeha.

Rezultati svake čestice u skali protežu se od 0 (nikada ne utječe) do 5 (jako utječe), što ukazuje na stupanj demotiviranosti studenata povezan s česticom. Ukupan rezultat iz skale dobit će se zbrojem rezultata za svaku česticu. Kada se ukupan rezultat skale uzme u obzir, stupanj demotiviranosti je izravno proporcionalan. Što je viši rezultat, to je veća demotiviranost studenata. Drugim riječima, nula (0) znači da se studenti ne suočavaju s faktorima koji ih demotiviraju te da su motivirani za učenje engleskog jezika. Za razliku od spomenutog rezultat 100 ukazuje na to da su studenti visoko demotivirani prema engleskome jeziku i nastavi engleskoga jezika, što ometa učenje. Rezultati skala podkomponenti pokazuju koliko određeni faktor demotivira studente u procesu učenja.

Najniži mogući rezultat iz skale demotivacije s 20 čestica je nula, a najviši 100 . Najniži rezultat dobiven iz podataka prikupljenih od 454 studenta je 0, a najviši 100. Prema tome, sveobuhvatni dobiveni rezultati pokrivaju opseg skale.

\section{Pouzdanost skale}

Cronbachov alfa koeficijent za pouzdanost skale bio je 0,911. Cronbachov alfa koeficijenti za podkomponente bili su: 0,$847 ; 0,813 ; 0,780$ i 0,768 . Ti rezultati pokazuju 
da je Cronbachov alfa koeficijent pouzdanosti skale prilično visok i mogu se smatrati pokazateljima da skala mjeri pouzdano.

\section{Valjanost skale}

Za dobivanje dokaza za valjanost konstrukta jednofaktorske strukture s četiri podkomponente dobivene nakon EFA s Promax rotacijom primijenili smo CFA. CFA na istim podacima otkrio je jednaku strukturu. Otkriveno je da su sva faktorska opterećenja statistički značajna $(\mathrm{p}<0,05)$. Indeksi pristajanja bili su RMSEA $=0,060$; $\mathrm{CFI}=0,93 ; \mathrm{GFI}=0,91 ; \mathrm{AGFI}=0,89 ; \mathrm{SRMR}=0,048$. Ta otkrića sugeriraju da je osiguran model pristajanja. Hi-kvadrat $\left(\mathrm{X}^{2}=429,33 ; \mathrm{DF}=164\right)$ bio je statistički značajan, aX $\mathrm{X}^{2} \mathrm{df}$ 2,61. Taj je rezultat dokaz da je model imao prihvatljiv indeks najboljeg pristajanja.

Sljedeći dokaz valjanosti konstrukta može se vidjeti u diskriminatornoj prirodi skale. Odnosno, skala može diskriminirati poznate skupine s obzirom na nisku korelaciju s instrumentima koji mjere drugi konstrukt; ili razlike između poznatih skupina (Aiken, 1996; Tezbaşaran, 2008). Dakle, da bi se uočila diskriminatorna priroda skale, odabrana je varijabla spol za provjeru podataka jer je u literaturi uočeno da su faktori demotivacije za muške i ženske studente (Muhonen, 2004; Kaivanpanah i Ghasemi, 2011).

T-testom za nezavisne uzorke saznali smo ukazuju li razine demotiviranosti studenata prema engleskome jeziku i nastavi engleskoga jezika na razlike prema spolu. Rezultati analize pokazali su da je srednja vrijednost za studentice $(n=229)$ $\mathrm{u}$ svim podkomponentama skale viša nego kod studenata $(\mathrm{n}=225)$. Ipak, kada se značajne razine svake podkomponente skale uzme u obzir, uviđamo da su, za razliku od podkomponenti „karakteristika nastavnika“ $\left(t_{452}=1,653 ; p=0,099>0,05\right)$ $i$ "nedostatka interesa prema engleskome jeziku i nastavi engleskoga jezika" $\left(\mathrm{t}_{452}=0,229 ; \mathrm{p}=0,819>0,05\right)$, studentice značajno više demotivirane od studenata $\mathrm{u}$ podkomponentama skale "razredno okruženje i nastavni materijali" $\left(\mathrm{t}_{452}=2,275\right.$; $\mathrm{p}=, 023<, 05)$ i "doživljaj neuspjeha" $\left(\mathrm{t}_{452}=2,253 ; \mathrm{p}=0,025<0,05\right)$. $\mathrm{U}$ svome istraživanju Muhonen (2004) je uočila da su studenti (muški) više demotivirani karakteristikama nastavnika, a da su studentice više demotivirane nastavnim materijalima. Nadalje, Kaivanpanah i Ghasemi (2011) su u svome istraživanju naglasili da su studentice više demotivirane karakteristikama nastavnika i doživljajem neuspjeha od studenata. Prema tome, u svjetlu tih pronalazaka, može se reći da je skala diskriminativne prirode.

\section{Rasprava zaključak}

U ovome istraživanju sudjelovala su 454 studenta pripremnih razreda za fakultet, odgovorivši na skalu od 50 čestica koja je razvijena da bi se identificirali faktori koji utječu na razine demotiviranosti studenata na fakultetu prema engleskome jeziku i nastavi engleskoga jezika. Analizirane su i pouzdanost i valjanost skale. Koristeći se analizom čestica prema Pearsonovoj korelaciji, čestice čiji koeficijent korelacije nije bio nula izostavljeni su iz skale, te je provjeren faktor opterećenja skale od 20 čestica. 
Koristeći se metodom Promax rotacije, dobili smo strukturu jednoga faktora $s$ četiri podkomponente i 20 čestica. Te podkomponente naslovljene su Karakteristike nastavnika, Nedostatak interesa prema engleskome jeziku i nastavi engleskoga jezika, Razredno okruženje i nastavni materijali, Doživljaj neuspjeha.

Sakai i Kikuchi (2009) identificirali su šest osnovnih faktora (nastavnici, doživljaj neuspjeha, karakteristike razreda, razredno okruženje, nastavni materijali i nedostatak interesa) nakon analize određenoga broja lokalno objavljenih studija demotiviranosti u kontekstu učenja engleskoga jezika u Japanu. Nadalje, Dörnyei (u Dörnyei i Ushioda, 2011, str. 150-151) također raspravlja o tim kategorijama u koje uvrštava svojih devet kategorija kao primjere. Kada usporedimo naše rezultate sa šest osnovnih kategorija demotivacije Sakaia i Kikuchia (2009), faktori demotivacije (Karakteristike nastavnika, Nedostatak interesa prema engleskome jeziku i nastavi engleskoga jezika, Razredno okruženje i nastavni materijali, Doživljaj neuspjeha) identificirani u ovome istraživanju preklapaju se s popisom Sakaia i Kikuchia, ali s određenim razlikama. Primjerice, Sakai i Kikuchi (2009) identificirali su „,razredno okruženje“, „,nastavne materijale“ i „karakteristike nastave“ kao različite faktore demotivacije, a ti su faktori pronađeni $\mathrm{u}$ istoj kategoriji pod nazivom „Razredno okruženje i nastavni materijali“ $u$ ovome istraživanju.

Nadalje, kada se s ovim istraživanjem usporede rezultati istraživanja iz drugih zemalja, faktori poput „upletanje drugoga stranoga jezika u učenje“ (Dörnyei, 1998; vidi Dörnyei i Ushioda, 2011), "kazne" (Chang i Cho, 2003), "gramatičko-prijevodna metoda" (Falout i sur., 2009; Kikuchi, 2009), "istodobno učenje drugih jezika" (Alavania i Sehat, 2012), "fokus na tešku gramatiku" (Ghadirzadeh, Hashtroudi, i Shokri, 2012) i "stavove prema engleskoj govornoj zajednici" (Dörnyei, 1998, vidi Dörnyei i Ushioda, 2011; Falaut i Maruyama, 2004; Kaivanpanah i Ghasemi, 2011), u ovome istraživanju nisu primijećeni. To možemo pripisati činjenici da ti faktori mogu biti svojstveni kontekstu učenja engleskoga jezika u drugim zemljama [pa čak i samim školama] u kojima su istraživanja provedena (Sakai i Kikuchi, 2009).

Cronbachov alfa koeficijent pouzdanosti skale od 0,911 i Cronbachov alfa koeficijent za podkomponente od 0,$847 ; 0,813 ; 0,780 ; 0,768$ govore da skala u cijelosti i zasebno sa svakom podkomponentom skale omogućuje pouzdano mjerenje.

CFA se koristio za provjeru valjanosti konstrukta skale. Rezultati CFA pokazuju da podaci odgovaraju dobivenome modelu. To također potvrđuje zaključak da skala ima strukturu jednoga faktora (jedan faktor s četiri podkomponente). Visoka korelacija među podkomponentama također podržava činjenicu da skala ima jedan faktor.

Za dobivanje dodatnih dokaza o valjanosti konstrukta skala, napravljena je analiza razlika prema spolu. Kada se uzmu u obzir podkomponente skale, iako nisu uočene značajne razlike kod karakteristika nastavnika i nedostatka interesa prema engleskome jeziku i nastavi engleskoga jezika, s obzirom na spol značajna je razlika uočena kod doživljaja neuspjeha i razrednog okruženja i nastavnih materijala. Kaivanpanah i Ghasemi (2011) u svome istraživanju naglašavaju postojanje značajne razlike s 
obzirom na spol kod podkomponenti karakteristike nastavnika i doživljaj neuspjeha, ali ne kod razrednog okruženja i nedostatka interesa. Meshkat i Hassani (2012) u svome istraživanju ukazuju na značajnu razliku kod sadržaja učenja i materijalima te nastavničke kompetencije i stilova poučavanja s obzirom na spol studenata.

Za provjeru valjanosti strukture dobivene u EFA, pokrenuta je CFA koristeći se identičnim podacima. Ipak, za provjeru valjanosti strukture trebalo bi testirati različite podatke (uzorke) kako bi se za nju dobili izravni dokazi.

Ovo je istraživanje provedeno među studentima na pripremnim satima engleskoga jezika škole za strane jezike. Stoga se preporučuje da se faktori demotivacije studenata prema engleskome jeziku i nastavi engleskoga jezika istraže i na drugim fakultetima. Druga preporuka je da se spomenuta skala za studente na fakultetima primijeni i na učenike u osnovnim i srednjim školama. 